
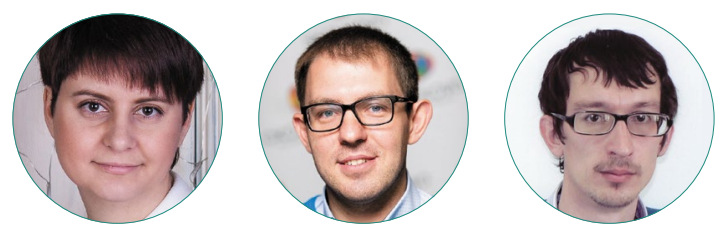

О. Е. Акимова, С. К. Волков, Е. Г. Ефимов

\title{
ПРИВЛЕКАТЕЛЬНОСТЬ РОССИЙСКИХ ТЕРРИТОРИЙ: ОЦЕНКА МНЕНИЙ ЦЕНТЕНИАЛОВ
}

\section{Правильная ссылка на статью:}

Акимова О.Е., Волков С. К., Ефимов Е.Г. Привлекательность российских территорий: оценка мнений центениалов // Мониторинг общественного мнения: экономические и социальные перемены. 2021. № 4. С. 384-404. https://doi.org/10.14515/monitoring.2021.4.1908.

\section{For citation:}

Akimova O.E., Volkov S. K., Efimov E. G. (2021) The Appeal of Russian Regions: Views of the Generation Z. Monitoring of Public Opinion: Economic and Social Changes. No. 4. P. 384-404. https://doi.org/10.14515/monitoring.2021.4.1908. (In Russ.) 
ПРИВЛЕКАТЕЛЬНОСТЬ РОССИЙСКИХ ТЕРРИТОРИЙ: ОЦЕНКА МНЕНИЙ ЦЕНТЕНИАЛОВ

АКИМОВА Ольга Евгеньевна - кандидат экономических наук, доцент кафедры “Экономика и предпринимательство", Волгоградский государственный технический университет, Вогоград, Россия

E-MAIL: akimovann25@mail.ru https://orcid.org/0000-0001-6967-7608

ВолКОВ Сергей Константинович кандидат экономических наук, доцент кафедры "Экономика и предпринимательство", Волгоградский государственный технический университет, Волгоград, Россия

E-MAIL: ambiente2@rambler.ru

https://orcid.org/0000-0002-4852-145X

ЕФИМОВ Евгений Геннадиевич - доктор социологических наук, профессор кафедры «История, культура и социология", Волгоградский государственный технический университет, Волгоград, Россия

E-MAIL:ez07@mail.ru

https://orcid.org/0000-0003-1843-7449

Аннотация. Статья посвящена выявлению факторов привлекательности российских территорий как места проживания с позиции поколения центениалов. Эмпирической базой исследования выступают данные опроса, проведенного методом онлайн-анкетирования в июле и августе 2020 г. среди студентов шести вузов Волгограда $(N=974)$. Подбор респондентов осуществлялся методом неслучайной выборки ("снежного кома"). Средний возраст опрошенных составил 19 лет, что позволяет рассматривать их как представителей поколения центе-
THE APPEAL OF RUSSIAN REGIONS: VIEWS OF THE GENERATION Z

Olga E. AKIMOVA 1 - Cand. Sci. (Econ.), Associate Professor at the Department of Economy and Entrepreneurship E-MAIL: akimovann25@mail.ru https://orcid.org/0000-0001-6967-7608

Sergei K. VOLKOV ${ }^{1}$ - Cand. Sci. (Econ.), Associate Professor at the Department of Economy and Entrepreneurship E-MAIL: ambiente2@rambler.ru https://orcid.org/0000-0002-4852-145X

Evgeni G. EFIMOV ${ }^{1}$-Dr. Sci. (Soc.), Professor at the Department of History, Culture and Sociology

E-MAIL: ez07@mail.ru

https://orcid.org/0000-0003-1843-7449

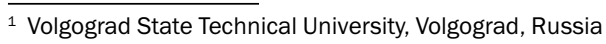

Abstract. The article focuses on identifying factors of attractiveness of Russian territories as a place of residence from the standpoint of the generation $Z$. The empirical basis of the study is an online survey conducted in July-August 2020 among students of six Volgograd universities $(N=974)$. All the respondents belong to generation Z (average age 19) and were selected by the method of non-random sampling ("snowball”). The participants of the study had to choose the priority factors (based on the author's model) that make certain territories attractive for living. 
ниалов. Респондентам предлагалось выбрать приоритетные факторы привлекательности территорий из предложенных в авторской модели.

Главным фактором привлекательности для опрошенных стал экономический (уровень заработной платы, трудоустройство и т.д.). Другими факторами в порядке убывания были названы: социальный, географический, культурно-досуговый, технологический и политический. В качестве рекомендаций авторы, с опорой на примеры зарубежного опыта, делают акцент на возможность стимулирования развития городской среды по ряду показателей для удержания молодежи (проактивная образовательная модель, развитие "креативных" отраслей экономики, формирование чистой экосистемы). Подчеркивается системный характер эффектов реформирования проблемных сфер, возможность стимулирования молодежи к региональной оседлости через создание комфортной городской среды.

Ключевые слова: региональное развитие, факторы привлекательности территории, теория поколений, миграция населения, города

Благодарность. Исследование выполнено при финансовой поддержке РНФ, проект № 21-18-00271 «Логика, институты и стратегии развития "сжимающихся" старопромышленных городов: синтез гетеродоксальных подходов".
According to the results, the main factor of attractiveness is the economic one (the level of wages, employment, etc.). Other factors which were named are the following (in descending order): social, geographic, cultural and leisure, technological and political. In conclusion, the authors give recommendations on stimulating the development of the urban environment to attract and retain young people (a proactive educational model, "creative" sectors of the economy, healthy ecosystem). The authors emphasize the importance of a comfortable urban environment to stimulate young people to settle in the region and point out that reforms in problematic areas have effects of systemic nature.

Keywords: regional development, factors of territory attractiveness, theory of generations, cities, human migration

Acknowledgments. The study was supported by the Russian Science Foundation, Project No. 21-18-00271 “Logic, institutions and strategies of 'shrinking' former industrial cities: the synthesis of heterodox approaches". 


\section{Введение}

Перед большинством российских регионов и их руководителями остро стоит вопрос о привлечении дополнительных ресурсов развития, прежде всего человеческих. Данное обстоятельство обостряется отрицательной динамикой прироста населения [Рыбаковский, 2018], оттоком населения [Шагалкина и др., 2019; Ионцев, Рязанцев, Ионцева, 2016], дефицитным бюджетом [Поварова, 2017] и ограничениями внешней среды развития [Оборин, 2018; Климанов, Варданян, 2019]. Вымывание человеческого капитала из регионов не только грозит социально-экономическими проблемами развития субъектов РФ, но и с точки зрения национальной безопасности представляет серьезный геополитический вызов целостности страны.

Дополнительную актуальность проблеме оттока населения из регионов придает тот факт, что по итогу 2019 г. Росстат обнародовал статистику об уменьшении численности постоянного населения в российских регионах. Лидеры по убыли населения - Саратовская область (19 тыс. человек), Омская область (17,6 тыс.), Кемеровская область (16,5 тыс.), Волгоградская область (15,8 тыс.) и Алтайский край $\left(15,8\right.$ тыс.) ${ }^{1}$. Несмотря на то, что тенденция сокращения численности населения в данных регионах прослеживается уже давно, федеральная власть только сейчас начала предпринимать шаги по выявлению причин данных процессов. Так, в Государственной думе под руководством А. В. Жукова, первого заместителя председателя ГД, была создана рабочая группа по изучению неблагоприятной демографической ситуации в названных регионах РФ и выработке мер по ее улучшению. Регионов, лидирующих по убыли молодежи, гораздо больше. По данным Росстата, к их числу можно отнести Башкорстан и Татарстан, Удмуртскую Республику, Тюменскую, Челябинскую, Архангельскую, Кировскую, Нижегородскую, Свердловскую, Саратовскую, Волгоградскую, Ростовскую области, Пермский и Краснодарский край ${ }^{2}$. Этот факт, по мнению авторов настоящего исследования, может свидетельствовать о том, что ситуация достигла критического состояния и нуждается в срочном решении, а также о том, что исследования по изучению факторов, причин и тенденций оттока населения приобретают особую актуальность в разрезе отдельных регионов и даже конкретных поселений. Особую значимость приобретает оценка мнений центениалов, которые, согласно теории поколений, пришли на смену миллениалам. Немногочисленные исследования центениалов говорят о том, что данное поколение существенно отличается от всех предыдущих [Kaplan, 2020], и это необходимо учитывать при разработке стратегии улучшения демографической ситуации и сокращения оттока населения.

Целью настоящего исследования является выявление факторов привлекательности российских территорий как места проживания с позиции поколения центениалов и выработка возможных рекомендаций для органов государственной власти с целью разработки проактивных стратегий пространственного развития. Исследование проводилось на примере Волгограда (город-миллионник).

\footnotetext{
1 Росстат назвал регионы-лидеры по убыли населения // РИА Новости. 2020. 2 февраля. URL: https://ria. ru/20200202/1564165411.html (дата обращения: 26.08.2021).

2 Число выбывших по полу, возрасту и потокам передвижения //Витрина статистических данных. 2018-2020. URL: https://showdata.gks.ru/report/278006/ (дата обращения: 26.08.2021).
} 


\section{Генезис теории поколений}

Теория поколений имеет давнюю историю. Как и во многих других теориях, в ней выделяются количественный и качественный подходы. Основоположником количественного подхода можно назвать Огюста Конта, который предлагал из мерять историческую действительность интервалами в 15, 25, 30 лет с позиции отдельных периодов жизни семьи [Конт, 2012]. Основоположниками качественной теории принято считать немецкого философа Вильгельма Дильтея [Dilthey, 1924] и немецкого социолога Карла Мангейма. В 1928 г. Карл Мангейм впервые в своем эссе "Проблема поколений" рассмотрел поколение как социологический феномен. Он дал определение термину «поколение», а также выявил, что значимые исторические события или социально-историческая среда формируют опыт молодежи, который определяет их жизненную мотивацию, нравственные ценности и поступки. Поколение определяется им как слой людей, сходство которых в большой мере обусловлено сходством жизненного опыта [Мангейм, 1998: 16]. Впоследствии испанский философ Хосе Ортега-и-Гассет доказал, что поколенческие структуры крайне важны, поскольку общепринятые традиции определенных поколений выступают как главная сила, ограничивающая человеческий выбор [Ортега-и-Гассет, 2002].

В 1991 г. появилось исследование Уильяма Штрауса и Нила Хоува "Поколения" ("Generations"), в котором описывались поколенческие циклы США, начиная c XV века [Strauss, Howe, 1991]. С позиции исторических событий авторы выделили архетипы, соответствующие каждой эпохе, а также представили свое определение термина "поколение». В цикле "Миллениума" ими было выделено четыре поколения: бэби-бумеры, поколение X, поколение Y, поколение Z [ibid.]. Несмотря на критику данной теории, она получила распространение во многих странах мира, была проверена в ЮАР, в европейских и азиатских странах, России и доказала свою универсальность.

В России социологическое изучение поколений с помощью глубинных биографических полуструктурированных интервью началось в 1990 г. в Институте социологии РАН в рамках проекта "Век социальной мобильности в России", результаты которого были отражены лишь в 1996 г. в работе В. Семеновой и Е. Фотеевой “Судьбы людей: Россия XX век: биографии семей как объект социологического исследования" [Семенова, Фотеева, 1996]. Впоследствии В. Семенова продолжила изучение последнего советского поколения, что нашло отражение в исследовании "Социальная динамика поколений: проблема и реальность" [Семенова, 2009].

Первое масштабное исследование поколения "бэби-бумеров" было проведено антропологом Алексеем Юрчаком [Yurchak, 2006], позже работы в данном направлении были продолжены социологом Михаилом Анипкиным [Анипкин, 2018]. О значимости поколенческой истории России неоднократно писал Теодор Шанин, профессор Московской высшей школы социальных и экономических наук. Ученый утверждал, что “есть периоды, когда важность поколенческого разделения общества резко увеличивается. Так, во время кризисов вопрос о разнице между поколениями становится центральным <...>. Без поколенческой истории, учета особого влияния поколений и влияния поколенчества 
на наше понимание истории и на историю нельзя понять многое из происходящего" [Шанин, 2005: 10-11].

В настоящее время в России запущен проект "Теория поколений в России Rugenerations", координатором которого выступает Евгения Шамис. В его рамках проводятся различные исследования поколений X, Y и Z с позиции маркетинга, рекламы, выявления портрета потребителя и сотрудника, возможности управления поколениями и т.д. [Шамис, Никонов, 2017].

Стоит отметить, что во многих зарубежных исследованиях поколений первостепенное внимание уделяется историческому, социальному и поведенческому аспектам. Ученых прежде всего интересует, какие исторические события способствовали формированию поколений, каковы их ценности, мотивация, особенности поведения, восприятия и анализа информации [Miller, 2011; Aanestad, 1993]. В России, в отличие от западных стран, данные исследований о поколениях используются не только в научных, но и в практических целях: в маркетинге, образовании, работе с персоналом. Большое число статей посвящено управлению персоналом и его мотивации, технологиям и особенностям ведения образовательного процесса в контексте теории поколений [Радаев, 2019; Кириллова, Гусева, 2015; Асташова, 2014; Ueberwimmer, Blyznyuk, 2016]. Многие компании разрабатывают и внедряют различные технологии подбора персонала в зависимости от принадлежности к тому или иному поколению.

В научной среде в последнее время развернулась активная дискуссия относительно определения поколения центениалов. Так, Марина Мирошкина полагает, что смена поколений в России носит дискретный характер. Представителей поколения Z, родившихся в интервале с 2004 по 2024 г., она называет цифровым поколением, или поколением Путина [Мирошкина, 2017]. Алексей Юрчак полагает, что "цифровое поколение" - это поколение периода 2000-2020 гг., рожденное во времена развития цифровых технологий, что обуславливает совершенно иные условия социализации, становления личности и взаимодействия с миром, неразрывно связанные с интернетом [Юрчак, 2014]. По мнению Валерии Захаровой, «поколение Z в России гораздо больше соотносится с поколением Z в других странах. Если для поколения X в нашей стране были присущи яркие особенности, вызванные глобальной исторической переменой - развалом СССР, то для Z всеохватывающее влияние интернета характерно и для нашей страны, и для мира в целом" [Захарова, 2019: 53]. В российских реалиях поколению Z (центениалам) соответствует молодежь, родившаяся в 2000-2020 гг. Это поколение, которое "рождается в период кризиса, когда общая угроза стирает некоторые социальные и политические противоречия, но создает высокую степень объединения общества, агрессивные государственные институты и этику самопожертвования" [Ожиганова, 2015: 94].

В последнее время все большее число исследователей интересуют вопросы зависимости цифрового поколения от цифровых технологий, социальных сетей и медиа [Цымбаленко, Макеев, 2015; Лапидус, Гостилович, Омарова, 2020], а также вопросы обучения цифрового поколения - каковы особенности преподавания современным студентам, каким образом они делают выбор в пользу того или иного учебного заведения, что определяет их выбор. Например, исследование Марины 
Воробьевой подчеркивает значимость новых образовательных технологий в процессе обучения: представители цифрового поколения хотели бы сосредоточиться на творчестве в классе, им важна креативность, они учатся лучше, когда вовлечены в процесс создания чего-то нового, когда они чувствуют сопричастность [Воробьева, 2019: 110]. Ряд ученых пытались составить портрет абитуриента и студента поколения Z, а также определить механизм работы преподавателей с представителями цифрового поколения [Коатс, 2011; Ярмак, Дерюгин, 2019; Горшков, Шереги, 2010; Захарова, 2019].

При этом практически ни одно из исследований не затрагивает особенностей экономического развития территорий с позиции теории поколений, особенно с учетом мнения центениалов. Из всего многообразия современных научных работ можно выделить как минимум две затрагивающие проблемы миграции населения, в том числе молодежи, из провинциальных городов. М. Гильтман, В. Пить, М. Батырева и Е. Сумик из Тюменского государственного университета провели эмпирический анализ отношения занятых в возрасте 24-64 года к городам их проживания, который показал наличие прямой связи между этим отношением и удовлетворенностью такими характеристиками, как развитые архитектура и градостроительство, эффективная система управления городом, хорошие ландшафты и озеленение [Гильтман и др., 2020]. Однако данное исследование затрагивало занятое взрослое население, а характеристики привлекательности не были сведены в обобщающие группы. Второе исследование, проведенное А. Одинцовым, А. Шипициным и А. Марченко из Волгоградского государственного социально-педагогического университета, направлено на выявление причин и тенденций центростремительной миграции молодежи из российской провинции [Одинцов, Шипицин, Марченко, 2020]. Однако в данной работе нет фокуса на исследовании именно центениалов, а респонденты самостоятельно оценивали Волгоград в сравнении с другими регионами, то есть объединенные факторы привлекательности не выявлялись. Безусловно, оба эти исследования в той или иной степени представляют интерес для нашей работы, однако нам хотелось бы понять, что привлекает именно центениалов в месте их проживания, какие факторы привлекательности территории наиболее значимы для них, насколько часто они меняют место жительства, какие сферы экономической деятельности получат свое развитие при поколении Z, как следует менять экономическую инфраструктуру и т.д.

\section{Методология исследования}

Анализ отечественных работ по выявлению причин привлекательности регионов выявил гипертрофированный интерес исследователей к вопросам их инвестиционной привлекательности [Сафиуллин, 2009; Мякшин, 2014; Емельянова, Харчикова, 2019] в ущерб выявлению и обоснованию факторов, способствующих удержанию местного населения и привлечению новых жителей. В этой связи мы выделили шесть групп факторов привлекательности территории с позиции населения: географические, экономические, социальные, культурно-досуговые, технологические и политические (см. рис. 1). Каждый из этих факторов включал в себя ряд базовых характеристик (подфакторов). 


\section{Рис. 1. Факторы привлекательности территории}

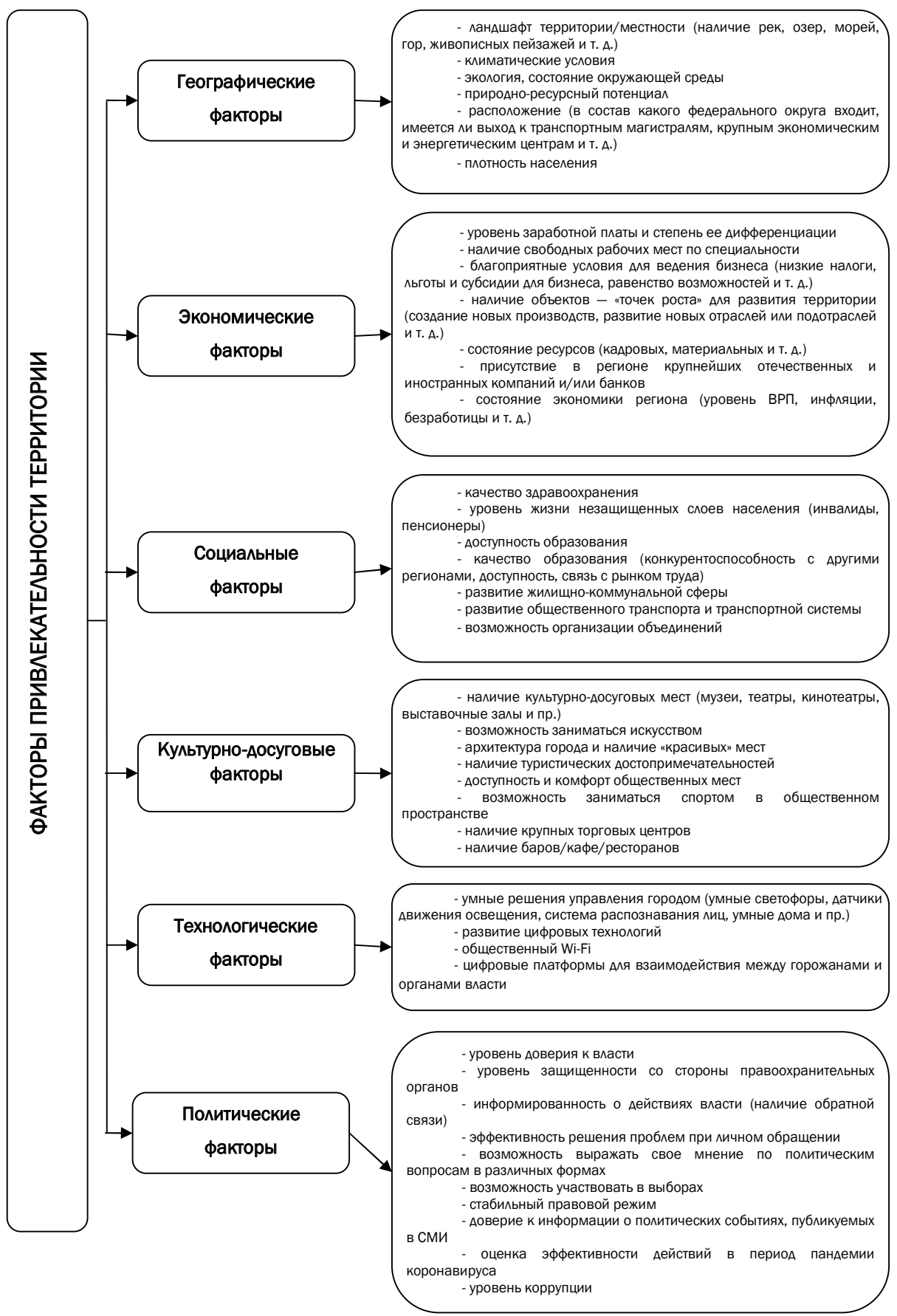


Далее мы провели социологическое исследование с целью выявления наиболее значимых факторов привлекательности российских территорий как места проживания с позиции поколения центениалов. Сбор данных проводился методом анкетирования в период с 8 июля по 11 августа 2020 г. Опрос был анонимным, использовалась онлайн-анкета, созданная на платформе "Яндекс. Формы" (https://yandex.ru/forms/). Выбор формата опроса был обусловлен невозможностью проведения очных встреч и бесед с респондентами в силу неблагоприятной санитарно-эпидемиологической обстановки, вызванной пандемией коронавируса. Важность изучения учащихся вузов как потенциально значимой силы в развитии региона и необходимость апробации новых подходов к исследованию поколения центениалов определили выбор студентов-центениалов в качестве объект нашего исследования. Рекрутинг респондентов проводился через информирование учащихся сотрудниками вузов по каналам электронной коммуникации (почта, мессенджеры). В опросе приняли участие 974 студента из шести вузов города: Волгоградский государственный технический университет (ВолгГТУ), Волгоградский государственный университет (ВолгГУ), Волгоградский государственный социально-педагогический университет (ВГСПУ), Волгоградский государственный аграрный университет (ВолгГАУ), Российская академия народного хозяйства и государственной службы при Президенте РФ (РАНХиГС), Волгоградский государственный медицинский университет (ВолГМУ). Географическая принадлежность студентов включала жителей Волгоградской области (из Волгограда, городов областного значения - Волжский, Камышин, Михайловка и др., сел и хуторов), а также, в единичных случаях, обучающихся в волгоградских вузах иностранных студентов и учащихся из других российских регионов (Москва, Астрахань и т. д.). В исследовании использовалась неслучайная выборка (метод "снежного кома"). Социально демографический состав был представлен следующими показателями: мужчины - 564, женщины - 412; бакалавры - 736, специалитет - 176, магистранты - 64; средний возраст респондентов - 19 лет. Задача репрезентативности выборки не ставилась. Результаты исследования могут распространяться только на выборочную совокупность и использоваться как справочные.

\section{Результаты исследования}

В анкете, помимо паспортной части, были представлены два блока вопросов. Первый включал переменные, оценивающие мобильность центениалов, их готовность к смене места проживания. Данный блок содержал открытые вопросы, в которых респондентам предлагалось назвать предпочтительные варианты эмиграции. Он также включал вопросы о миграции в сельскую местность, где в случае утвердительного или отрицательного ответа предлагалось указать причины сделанного выбора. Ответы на открытые вопросы анализировались через подсчет слов в общем массиве ответов респондентов. Во втором блоке вопросов респондентам нужно было ранжировать по степени важности предложенные авторами факторы привлекательности территории.

Опрос показал, что все центениалы являются активными пользователями интернета - 96,4\% пользуются им ежедневно. Это соответствует как отечественным, так и западным характеристикам данного поколения [Rue, 2018]. При этом, несмо- 
тря на общий рост в последние годы востребованности интернета у всех возрастных групп ${ }^{3}$, согласно опросу Фонда "Общественное мнение", молодежь использует его активнее, в том числе для доставки готовой еды, продуктов и товаров 4 .

Доля центениалов, не готовых к перемене места жительства (37,2\%) меньше, чем совокупная доля тех, кто хочет уехать в другой регион (34,2\%) или в другую страну (28,8\%) (см. рис. 2).

\section{Рис. 2. Готовность центениалов к перемене места жительства}

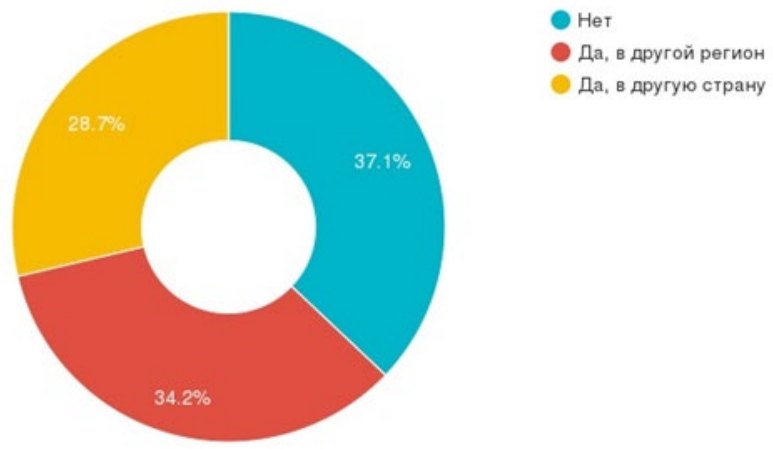

Среди привлекательных для эмиграции стран с большим отрывом лидируют США, ФРГ и Канада (см. рис. 3), а среди российских регионов и городов - Москва и Санкт-Петербург, а также Краснодарский край. В топ-5 привлекательных регионов вошли также Ростов-на-Дону и Республика Татарстан (см. рис. 4).

Рис. З. Наиболее привлекательные для миграции центениалов из Волгоградской области страны

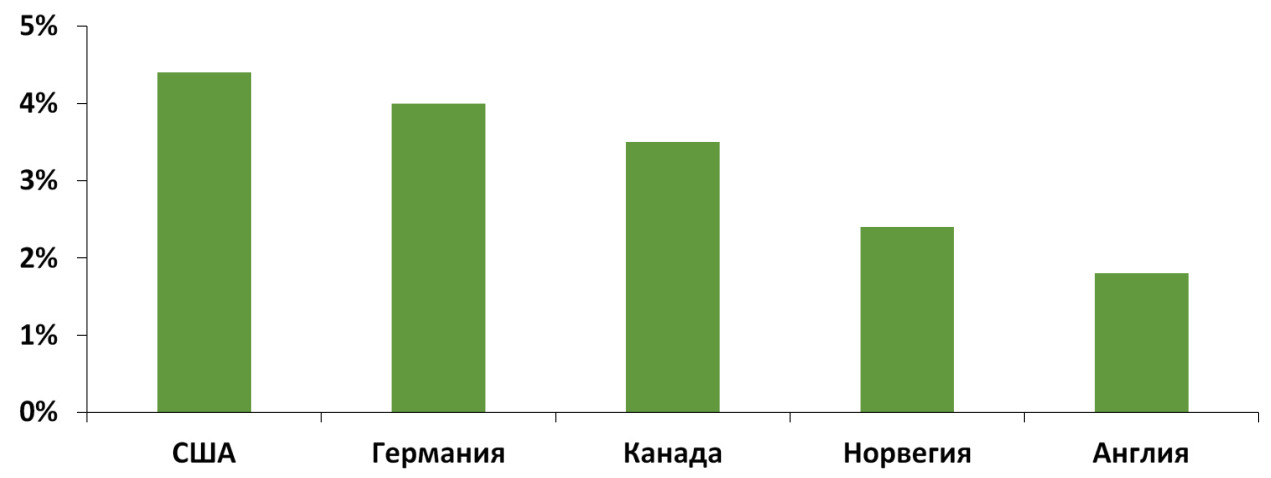

\footnotetext{
${ }^{3}$ Жизнь без компьютера - уходящая натура? (аналитический обзор) //ВЦИОМ. 2020. 6 августа. URL: https://wciom. ru/index.php?id=236\&uid=10394 (дата обращения: 27.08.2021).

4 Интернет и онлайн-сервисы //ФОМ. 2020. 31 мая. URL: https://fom.ru/SMI-i-internet/14402 (дата обращения: 27.08.2021).
} 
Рис. 4. Наиболее привлекательные для миграции центениалов из Волгоградской области регионы РФ

$11 \%$

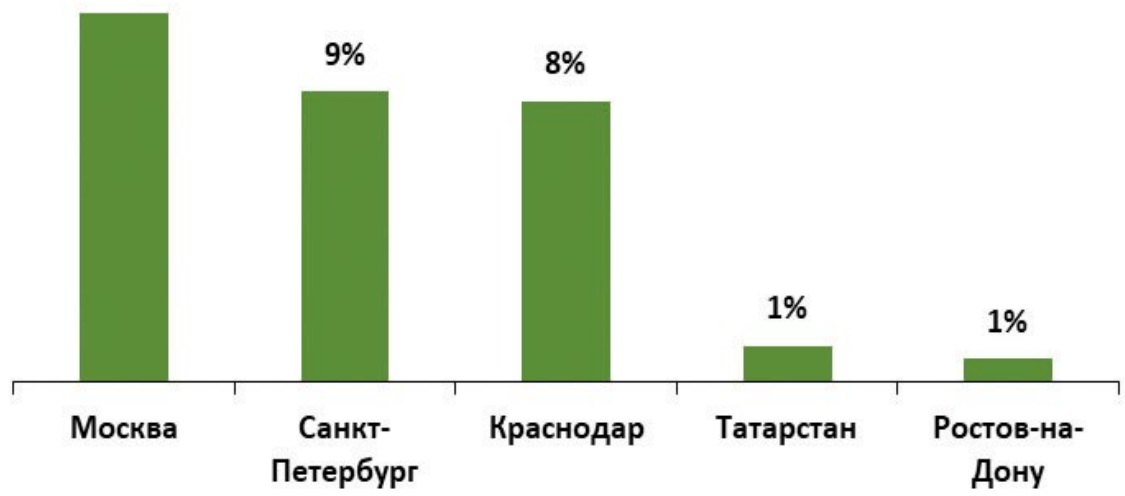

В ходе опроса респондентам предлагалось выбрать из предложенных факторов привлекательности территории те, которые они считают решающими при выборе места проживания. В анкете были перечислены шесть факторов: экономический, социальный, географический, культурно-досуговый, технологический, политический, и участникам опроса сначала нужно было выбрать три из них, а затем в рамках выбранных факторов проранжировать их критерии по степени значимости (для представления о перечне критериев см. рис. 1). Необходимость данного ограничения обусловлена задачей выявления наиболее значимых факторов регионального развития с целью изучения их возможной трансформации.

На первом месте по важности для респондентов оказался экономический фактор (26,6\%) (см. рис. 5), внутри которого выделяются уровень заработной платы и степень ее дифференциации (30,2\%), а также наличие свободных рабочих мест по специальности (20,6\%) (см. рис. 6).

Рис. 5. Распределение факторов привлекательности территории по значимости для центениалов

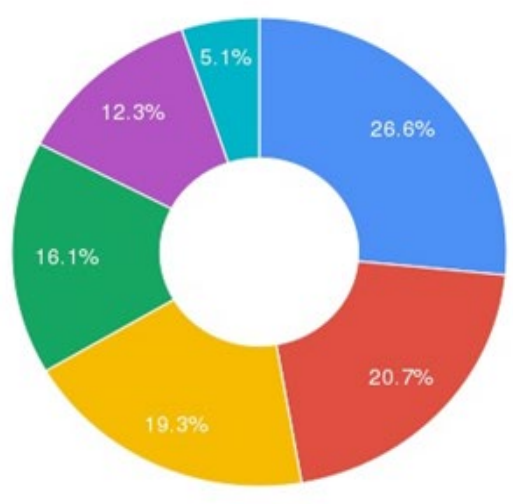

Экономические факторы

Социальные факторы

Географические факторы

Культурно-досуговые факторы

Технологические факторы

Политические факторы 
Таким образом, присутствие на рынке труда рабочих мест не является для молодежи самодостаточным условием, поскольку предъявляются требования и к определенному уровню зарплат. В то же время для центениалов, принадлежащих западной культуре, характерны требования не только к зарплате, но и к условиям труда, которые должны быть гибкими и позволять строить карьеру по нескольким направлениям [Schroth, 2019]. Это может служить объяснением оттока центениалов из регионов в крупные города, где рынок труда отвечает их потребностям как по уровню зарплат, так и по качеству самих условий труда.

Рис. 6. Значимость экономических подфакторов для центениалов Волгоградской области

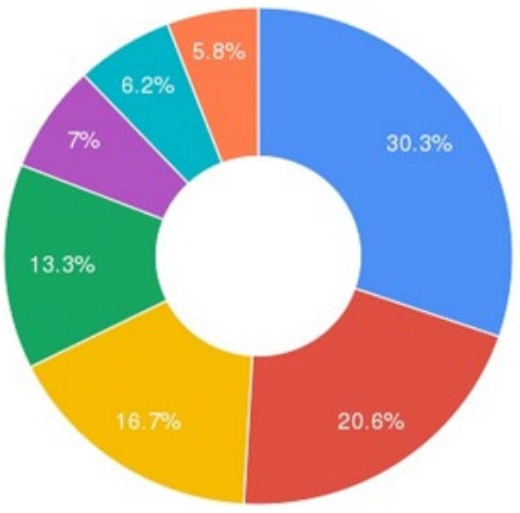

Уровень заработной платы и степень ее дифференциации

Наличие рабочих мест по специальности

Состояние экономики региона

Благоприятные условия для ведения бизнеса

Наличие объектов - "точек роста”

Присутствие в регионе крупнейших отечественных и иностранных компаний и/или банков

Состояние ресурсов

Среди социальных факторов большинство респондентов выделяют качество здравоохранения (22,3\%) и образования (18,5\%). Повышенное внимание к проблеме медицинского обслуживания населения может быть обусловлено пандемией COVID-19, однако в целом этот результат соответствует уже известному наблюдению о бережном отношении центениалов к своему здоровью ${ }^{5}$. Важность образования напрямую связана с его ролью в увеличении социальной мобильности.

В географическом факторе (19,3\%) решающая роль отводится климатическим условиям, а также экологии. Отметим, что в условиях городского пространства, в котором проживают большинство респондентов, речь может идти не только о региональных природно-климатических условиях, но и об оценке мероприятий по изменению городской среды.

Три вышеуказанных параметра приоритетны для опрошенных, в то время как культурно-досуговые, технологические и политические факторы не вызывают особого интереса. Среди культурно-досуговых факторов респонденты выделяют наличие культурно-досуговых и «красивых» мест. Незначительная роль культурного фактора может объясняться тем, что посещение тех или иных городских мест

\footnotetext{
5 Ценности поколений в России на 2020 год//Rugenerations - российская школа теории поколений. 2020. 17 июня. URL: https://rugenerations.su/2020/06/17/ценности-разных-поколений-в-россии-на-20/ (дата обращения: 27.08.2021).
} 
не считается приоритетным для поколения, социализация которого проходила в виртуальной среде. Среди технических факторов выделяют развитие цифровых технологий и "умное управление городом", но их в целом незначительная доля может объясняться акцентом на использовании персональных гаджетов. Политический фактор региональной привлекательности оценивался респондентами как наименее значимый (5,1\%). Для поколения центениалов важную роль играет эгоцентризм, объясняющий их нацеленность на анализ тех параметров, которые имеют значение для них в настоящий период времени и ближайшем будущем [Rue, 2018]. Поэтому политическое участие для них актуально в той мере, в которой это затрагивает их непосредственные интересы, что может вызывать "всплески" политической активности в контексте разных тем.

Для получения информации о возможных каналах социальной мобильности в рамках региона был сформулирован открытый вопрос об условиях проживания в сельской местности. Респондентов можно условно разделить на две группы. K первой относятся те, кто указал в качестве причин нежелания ехать в сельскую местность конкретные факторы развития, прежде всего технический (“нет нормального интернета»; “потому что в сельской местности часто не ловит связь" и т.д.) и экономический ("трудно с работой»; “отсутствие рабочих мест" и т.д.). Вторая группа никак не обосновала свое нежелание жить в сельской местности, выразив лишь общее негативное отношение к данной перспективе ("патамушта", "не нравится", "не хочется", "нет желания" и т.д.). При описании преимуществ проживания в сельской местности подавляющее большинство респондентов отмечали экологические условия ("свежий воздух", “чистый воздух", "природа" и т. д.), что также подтверждает важность географического фактора.

\section{Обсуждение и рекомендации}

Полученные в ходе исследования данные позволяют сформулировать ряд практических рекомендаций для повышения уровня привлекательности российских территорий для проживания центениалов. Эти рекомендации могут лечь в основу проактивных стратегий социально-экономического развития российских регионов.

Для центениалов главным фактором привлекательности территории выступают экономические стимулы - уровень заработной платы, наличие в регионе рабочих мест по специальности, возможность ведения бизнеса. Поэтому первоочередная задача регионального менеджмента заключается в том, чтобы обеспечить институциональные, инфраструктурные и нормативно-правовые условия для развития и диверсификации экономики и создания привлекательных для молодежи рабочих мест. Вопрос о структуре рынка труда и трудовых предпочтений поколения центениалов - это тема отдельного исследования. Однако уже сейчас понятно, что без удовлетворения базовой необходимости в материальном благополучии центениалов говорить о более высоких потребностях не приходится. Очевидно, что формирование привлекательного рынка труда предполагает его трансформацию и замещение привычных отраслей экономики новыми (креативными), что также потребует трансформации региональных систем подготовки специалистов (системы высшего и среднего профессионального образования). 
Второй крупный блок факторов привлекательности регионов для проживания центениалов - социальный. Новое поколение не только хочет получать достойную заработную плату и профессионально развиваться, но и предъявляет повышенные требования к качеству жизни и уровню оказания социальных услуг. Высокое качество здравоохранения, доступность и качество образования (как высшего, так и школьного), улучшение системы жилищно-коммунальной сферы - это те направления, на которые необходимо обратить внимание региональным властям, если они хотят развития экономики своих территорий за счет удержания и привлечения новых жителей. Высококачественные специалисты стремятся в те регионы, где существует развитая система социальной поддержки. Дополнительного изучения и анализа требует миграционный процесс абитуриентов из регионов в столичные вузы. Очевидно, что региональным университетам не хватает гибкости и адаптивности к запросам молодого поколения. Трансформация региональных вузов в сторону диверсификации и модернизации портфеля образовательных программ становится необходимым условием не только развития, но и выживания региональной системы высшего образования. Необходима не реактивная, а проактивная модель развития университетов в регионах.

Географический блок факторов привлекательности территории играет также важную роль. Климатические условия оказывают непосредственное влияние на выбор центениалами места их проживания. И хотя на географическое положение территорий трудно воздействовать со стороны региональных администраций, в их власти сделать жизнь более комфортной. В международной практике есть много примеров, когда муниципальные и региональные власти вкладываются в развитие инфраструктуры для повышения комфорта проживания местных жителей. К примеру, власти города Оклахома (США), расположенного посреди пустыни, для борьбы с пылью в городе создали по его периметру сеть искусственных озер, выступающих в качестве естественных фильтров. В итоге в городе практически нет пыли (в чем один из авторов данного исследования мог лично убедиться во время стажировки по программе "Открытый мир" в 2014 г.). Или пример города Дубай (ОАЭ), где в условиях экстремальной жары власти оборудовали кондиционерами все общественные места, вплоть до остановок общественного транспорта.

Стремление центениалов жить в экологически чистых местах - это не единичная история про Грету Тунберг, а общий тренд поколения ${ }^{6}$. В этой связи региональным властям следует предпринять все возможные меры по формированию чистой экосистемы своих территорий. Необходим пересмотр градостроительного подхода к проектированию современных городов. Советское наследие в виде грязных производств (фабрики, заводы, сборочные цеха, промышленные зоны и пр.) в черте города наносят не только экологический вред, но и негативно сказываются на привлекательности для потенциальных жителей и туристов. По возможности необходимо отказаться от энерго- и ресурсозатратных производств в черте города и вынести их далеко за территорию проживания местных жителей. Наличие пустующих земельных площадей в большинстве регионов страны позво-

\footnotetext{
${ }_{6}$ Barbiroglio E. Generation Z Fears Climate Change More Than Anything Else // Forbes. 2019. December 9. URL: https:// www.forbes.com/sites/emanuelabarbiroglio/2019/12/09/generation-z-fears-climate-change-more-than-anythingelse/\#3f54c877501b (дата обращения: 12.08.2020).
} 
ляет это сделать безболезненно и без задействования дополнительного капитала. Привлекательный ландшафт российских территорий позволит не только повысить качество жизни местного населения, но будет и способствовать развитию туризма.

Современные исследователи утверждают, что наличие в городе общественных пространств и досуговых мест оказывается конкурентным преимуществом в борьбе за привлечение туристов, способствует кластеризации креативных специалистов и повышает уровень счастья местных жителей [Florida, Mellander, Stolarick, 2011; Florida, Mellander, Rentfrow, 2013]. В условиях снижения реальных доходов населения и покупательной способности создание общественных пространств становится фактором уменьшения социальной напряженности. Люди должны иметь возможность получать качественные общественные блага. Эстетическая красота современных российских городов оставляет желать лучшего. Большинство из них представляют собой шаблонные проекты советской эпохи с четко обозначенным историческим центром города (как правило, где и расположены большинство достопримечательностей и общественных пространств) и обширными спальными районами (в которых развита только инфраструктура массового потребления). Необходимы девелоперские проекты по повышению уровня комфорта городских пространств.

Стимулирование малого и среднего бизнеса (торговые центры, лофтовые пространства, бары, кафе и рестораны) даст мультипликативный эффект не только с точки зрения экономической эффективности предпринимательства, но и будет способствовать удовлетворению социально-культурных потребностей жителей городов.

Вопреки нашим ожиданиям технологические факторы привлекательности территорий не столь важны для центениалов. Между тем данное обстоятельство требует дополнительных исследований в контексте межрегиональных сравнений - особенно в сравнении со столичными регионами. Поколение центениалов называют цифровыми аборигенами, поколением, которое не мыслит своего существования без использования цифровых технологий и различного рода гаджетов. Мы убеждены, что развитие цифровых технологий, повсеместный доступ к интернету, формирование цифровых платформ для взаимодействия между горожанами и различными городскими службами/сервисами станет неотъемлемой частью городов будущего. Уже сейчас мы наблюдаем тренд на трансформацию городского хозяйства в сторону "умного" устойчивого развития. Концепция "умный город" становится магистральной в развитии зарубежных территорий. Умные цифровые города должны формировать благоприятную экосистему для эффективного развития предпринимательства и обеспечить возможность для жителей участвовать в социальной жизни своих муниципалитетов [Basle, 2016].

\section{Заключение}

Поколение центениалов стремится в те регионы (города), где выше не только уровень жизни (экономические факторы), но и ее качество (социальные и культурно-досуговые факторы). Развитие территорий зависит от человеческого капитала, сконцентрированного в их границах, поэтому региональным властям необходимо создавать экономические условия для реализации базовых нужд населения и формировать комфортную и развитую городскую среду с широким набором 
бесплатных социальных благ. Совершенно очевидно, что без создания креативной и комфортной экосистемы современных городов и сельских поселений удержать молодое поколение в границах региональных образований будет очень сложно. Это влечет за собой проблему вымывания и стагнации человеческого капитала в ряде регионов, а также несет угрозу территориальной целостности.

Несмотря на актуальность и практическую значимость нашего исследования, оно не лишено методологических ограничений. Во-первых, опрос проводился в условиях неблагоприятной санитарно-эпидемиологической обстановки, Вызванной пандемией коронавируса, после продолжительного периода самоизоляции, что естественным образом сказалось на уровне благосостояния большинства жителей страны. Уменьшение реального дохода в расчете на отдельную семью могло отразиться на чистоте исследования из-за искусственного обострения значимости экономических факторов, которые, может быть, не играли бы принципиальную роль год/полгода назад. Во-вторых, опрос проводился в Волгограде - дотационном регионе с достаточно неблагоприятной ситуацией с точки зрения социальноэкономического развития. В рейтинге российских регионов по доходам населения за первое полугодие 2020 г. он занимает 60-е место (из 85). Доля населения, проживающего за чертой бедности и за чертой крайней бедности, составляет 12,9\% и 1,4\% соответственно ${ }^{7}$. Данное обстоятельство накладывает методологические ограничения и влияет на изначальный пессимистичный настрой респондентов. В-третьих, для более качественного анализа факторов привлекательности российских территорий с позиции центениалов необходимо провести очные фокусгруппы, что даст возможность детального и многоаспектного выявления мотивов поведения респондентов.

Осознавая данные ограничения и учитывая перспективность и многоаспектность данного направления исследования, мы видим его как один из этапов широкой исследовательской программы по изучению социально-экономических и поведенческих характеристик центениалов с точки зрения их участия в экономических процессах территорий. Перспективными направлениями для дальнейших исследований могут быть следующие: межрегиональное исследование социальноэкономических и поведенческих характеристик центениалов и их сравнение, выявление трудовых предпочтений центениалов, сравнительный анализ городских и сельских центениалов.

\section{Список литературы (References)}

Анипкин М. Поколение лишних людей: антропологический портрет последнего советского поколения // Неприкосновенный запас. 2018. № 117. С. 290-308. Anipkin M. (2018) Generation of Superfluous People: An Anthropological Portrait of the Last Soviet Generation. Emergency Reserve. No. 117. P. 290-308. (In Russ.)

Асташова Ю. В. Теория поколений в маркетинге // Вестник Южно-Уральского государственного университета. Серия: Экономика и менеджмент. 2014. Т. 8. № 1. С. $108-114$.

\footnotetext{
7 Рейтинг регионов по доходам населения - 2020//РИА Рейтинг. 2020. 7 июля. URL: https://riarating.ru/ infografika/20200707/630174723.html (дата обращения: 27.08.2021).
} 
Astashova Yu.V. (2014) The Theory of Generations in Marketing. Bulletin of the South Ural State University. Series: Economics and Management. Vol. 8. No. 1. P. 108-114. (In Russ.)

Воробьева М. В. Особенности и обучение І-поколения (поколения Z) // Педагогическое образование и наука. 2019. № 5. С. 108-112.

Vorobieva M. V. (2019) Features and Training of the I-Generation (Generation Z). Pedagogical Education and Science. No. 5. P. 108-112. (In Russ.)

Гильтман М. А., Пить В. В., Батырева М. В., Сумик Е. А. В каких городах нам нравится жить? Эмпирический анализ отношения занятых к городам // Журнал Новой экономической ассоциации. 2020. № 1. С. 111-130.

Giltman M. A., Pit V. V., Batyreva M. V., Sumik E. A. (2020) What Cities Do We Like to Live In? Empirical Analysis of the Attitude of the Employed to Cities. Journal of the New Economic Association. No. 1. P. 111-130. (In Russ.)

Горшков М.К., Шереги Ф.Э. Молодежь России: социологический портрет. М. : ЦСПиМ, 2010.

Gorshkov M. K., Sheregi F. E. (2010) Youth of Russia: a Sociological Portrait. Moscow: TsSPiM. (In Russ.)

Емельянова Е. В., Харчикова Н. В. Инновационный потенциал регионов Центрального федерального округа: оценка основных тенденций и перспектив развития // Экономика в промышленности. 2019. Т. 12. № 4. С. 443-454.

Emelyanova E. V., Kharchikova N.V. (2019) The Innovative Potential of the Regions of the Central Federal District: An Assessment of the Main Trends and Development Prospects. Economy in Industry. Vol. 12. No. 4. P. 443-454. (In Russ.)

Захарова В.А. Студенты поколения Z: реальность и будущее // Научные труды Московского гуманитарного университета. 2019. № 4. C. 47-55. https://doi.org/ 10.17805/trudy.2019.4.5.

Zakharova V. A. (2019) Generation Z Students: Reality and the Future. Scientific Works of the Moscow University for the Humanities. No. 4. P. 47-55. https://doi. org/10.17805/trudy.2019.4.5. (In Russ.)

Ионцев В. А., Рязанцев С. В., Ионцева С. В. Новые тенденции и формы эмиграции из России // Экономика региона. 2016. № 12. С. 499-509.

Iontsev V. A., Ryazantsev S. V., Iontseva S. V. (2016) New Trends and Forms of Emigration From Russia. Economy of the Region. No. 12. P. 499-509. (In Russ.)

Кириллова О.Г., Гусева Е.В. Место теории поколений в развитии современной теории управления персоналом // Экономика устойчивого развития. 2015. № 3. С. $273-278$.

Kirillova O.G., Guseva E. V. (2015) The Place of the Theory of Generations in the Development of Modern Theory of Personnel Management. Economics of Sustainable Development. No. 3. P. 273-278. (In Russ.)

Климанов В.В., Варданян В.Ш. Прогнозы регионов России в условиях экономических санкций // Региональная экономика. Юг России. 2019. № 3. С. 25-33. 
Klimanov V. V., Vardanyan V. Sh. (2019) Forecasts of Russian regions in the context of economic sanctions. Regional Economy. South of Russia. No. 3. P. 25-33. (In Russ.)

Коатс Дж. Поколения и стили обучения / пер. с англ. Л. Е. Колбачева. М. : Межгосударственная ассоциация последипломного образования. 2011.

Coates J. Generations and Learning Styles / Transl. from English L. E. Kolbachev. Moscow: Interstate Association of Postgraduate Education. (In Russ.)

Конт О. Общий обзор позитивизма / пер. с фр. И. А. Шапиро; под ред. Э. Л. Радлова. Изд. 3-е. М.: Книжный дом "ЛИБРОКОМ", 2012.

Cont O. General Overview of Positivism. Ed. E. L. Radlova. Ed. 3rd. Moscow: LIBROKOM. (In Russ.)

Лапидус Л. В., Гостилович А. О., Омарова Ш. А. Особенности проникновения цифровых технологий в жизнь поколения Z: ценности, поведенческие паттерны и потребительские привычки интернет-поколения // Государственное управление. 2020. № 83. C. 271-293. https://doi.org/10.24411/2070-1381-2020-10119. Lapidus L. V., Gostilovich A. O., Omarova Sh.A. (2020) Features of Digital Technologies Penetration into Generation Z Life: Values, Behavioral Patterns and Consumer Habits of the Internet Generation. Public Administration. No. 83. P. 271-293. https://doi. org/10.24411/2070-1381-2020-10119. (In Russ.)

Мангейм К. Проблема поколений // Новое литературное обозрение. 1998. № 2. C. $7-47$.

Mannheim K. (1998) The Problem of Generations. New Literary Observer. No. 2. P. 7-47. (In Russ.)

Мирошкина М.Р. Интерпретация теории поколений в контексте российского образования // Ярославский педагогический вестник. 2017. № 6. С. 30-35.

Miroshkina M. R. (2017) Interpretation of the Theory of Generations in the Context of Russian Education. Yaroslavl Pedagogical Bulletin. No. 6. P. 30-35. (In Russ.)

Мякшин В.Н. Факторы инвестиционной привлекательности региона и их оценка // Региональная экономика: теория и практика. 2014. № 14. С. 23-33.

Myakshin V. N. (2014) Factors of Investment Attractiveness of the Region and Their Assessment. Regional Economy: Theory and Practice. No. 14. P. 23-33. (In Russ.)

Оборин М. С. Управление агропромышленным комплексом и сельским хозяйством регионов России в условиях санкций // Экономика строительства и природопользования. 2018. № 4. С. 99-107.

Oborin M.S. (2018) Management of the Agro-Industrial Complex and Agriculture of the Regions of Russia Under the Conditions of Sanctions. Economics of Construction and Environmental Management. No. 4. P. 99-107. (In Russ.)

Одинцов А. В., Шипицин А. И., Марченко А. Ю. Центростремительная миграция молодежи из российской провинции: причины и тенденции (на примере Волгоградской области) // Мониторинг общественного мнения: экономические и социальные перемены. 2020. № 3. С. 335-354. https://doi.org/10.14515/monitoring. 2020.3.788. 
Odintsov A. V., Shipitsin A. I., Marchenko A. Yu. (2020) Centripetal Migration of Young People From the Russian Provinces: Causes and Trends (On the Example of the Volgograd Region). Monitoring of Public Opinion: Economic and Social Changes. No. 3. P. 335-354. https://doi.org/10.14515/monitoring.2020.3.788. (In Russ.)

Ожиганова Е. М. Теория поколений Н. Хоува и В. Штрауса. Возможности практического применения // Бизнес-образование в экономике знаний. 2015. № 1. С. 9497. URL: https://bibs-science.ru/articles/ar550.pdf (дата обращения: 26.08.2021). Ozhiganova E. M. (2015) The Theory of Generations by N. Hove and W. Strauss. Possibilities of Practical Application. Business Education in the Knowledge Economy. No. 1. P. 94-97. URL: https://bibs-science.ru/articles/ar550.pdf (accessed: 26.08.2021). (In Russ.)

Ортега-и-Гассет Х. Восстание масс. М.: Издательство АСТ, 2002.

Ortega-and-Gasset H. (2002) Revolt of the Masses. Moscow: AST Publishing House.

Поварова А. И. Исполнение бюджетов регионов в 2016 году: кризис не преодолен // Экономические и социальные перемены: факты, тенденции, прогноз. 2017. № 4. С. $144-161$.

Povarova A. I. (2017) Execution of Regional Budgets in 2016: The Crisis Has Not Been Overcome. Economic and Social Changes: Facts, Trends, Forecast. No. 4. P. 144-161. (In Russ.)

Радаев, М. Миллениалы: как меняется российское общество. М.:Изд. дом Высшей школы экономики, 2019.

Radaev, M. (2019) Millennials: How Russian Society is Changing. Moscow: The Higher School of Economics Publishing House. (In Russ.)

Рыбаковский О. Л. Демографическая динамика России: основные понятия, показатели, итоги за 1946-2017 // Народонаселение. 2018. № 4. С. 14-22.

Rybakovsky O. L. (2018) Demographic Dynamics of Russia: Basic Concepts, Indicators, Results for 1946-2017. Population. No. 4. P. 14-22. (In Russ.)

Сафиуллин А. Р. Инвестиционная привлекательность территории как фактор ее конкурентоспособности // Экономические стратегии. 2009. Т. 11. № 8. C. 140-149. Safiullin A. R. (2009) Investment Attractiveness of the Territory as a Factor of Its Competitiveness. Economic Strategies. Vol. 11. No. 8. P. 140-149. (In Russ.)

Семенова В.В. Социальная динамика поколений: проблема и реальность. М.: РОССПЭН, 2009.

Semenova V. V. (2009) Social Dynamics of Generations: Problem and Reality. Moscow: ROSSPEN. (In Russ.)

Семенова В. В., Фотеева Е. В. Судьбы людей: Россия XX век: биографии семей как объект социологического исследования. М. : Институт социологии РАН, 1996. Semenova V. V., Foteeva E. V. (2015) Fates of People: Russia XX Century: Biographies of Families as an Object of Sociological Research. Moscow: Institute of Sociology RAS. (In Russ.) 
Цымбаленко С. Б., Макеев П. Цифровое поколение - медийный портрет подростка // Народное образование. 2015. № 3. С. 201-212.

Tsymbalenko S. B., Makeev P. (2015) Digital Generation — A Media Portrait of a Teenager. Public Education. No. 3. P. 201-212. (In Russ.)

Шагалкина М.В., Латуха М. О., Мицкевич Е. А., Строгецкая Е. В. Факторы миграционных намерений талантливых выпускников ведущих вузов России // Российский журнал менеджмента. 2019. Т. 17. № 4. С. 445-466.

Shahalkina M. V., Latukha M. O., Mitskevich E. A., Strogetskaya E. V. (2019) Factors of Migration Intentions of Talented Graduates from Leading Russian Universities. Russian Management Journal. Vol. 17. No. 4. P. 445-466. (In Russ.)

Шамис Е., Никонов Е. Теория поколений. Необыкновенный Х. М. : Литрес, 2016. Shamis E., Nikonov E. (2016) Theory of Generations. Unusual H. Moscow: Litres. (In Russ.)

Шанин Т. История поколений и поколенческая история России //Человек. Общество. Управление. 2005. № 3. С. 6-25.

Shanin T. (2005) History of Generations and Generational History of Russia. Man. Society. Control. No. 3. P. 6-25. (In Russ.)

Юрчак А. Это было навсегда, пока не кончилось. Последнее советское поколение. М.: Новое литературное обозрение, 2014.

Yurchak A. (2014) It Was Forever, Until It Ended. The Last Soviet Generation. Moscow: New Literary Observer. (In Russ.)

Ярмак О.В., Дерюгин П.П., Ярмак В.Е. Социальный портрет современного студента // Дискурс. 2019. Т. 5, № 4. С. 53-64.

Yarmak O. V., Deryugin P. P., Yarmak V.E. (2019) Social Portrait of a Modern Student. Discourse. Vol. 5. No. 4. P. 53-64. (In Russ.)

Basle M. (2016) Smarter Cities' Attractiveness. Testing New Criteria or Facets: “Data Scientists" and "Data Platforms". Journal of the Knowledge Economy. No. 12. P. 268278. https://doi.org/10.1007/s13132-016-0398-0.

Dilthey W. (1924) Ueber das Studium der Geschichte der Wissenschaften vom Menschen, der Gesellschaft und dem Staat. In: W. Dilthei: Gesammelte Schriften. Bd. 5-6: Die geistige Welt. Leipzig; Berlin: Teubner. S. 36-41.

Florida R., Mellander C., Rentfrow P. J. (2013) The Happiness of Cities. Regional Studies. Vol. 47. No. 4. P. 613-627. https://doi.org/10.1080/00343404.2011.589830.

Florida R., Mellander C., Stolarick K. (2011) Beautiful Places: The Role of Perceived Aesthetic Beauty in Community Satisfaction. Regional Studies. Vol. 45. No. 1. P. 3348. https://doi.org/10.1080/00343404.2010.486784.

Kaplan E. (2020) The Millennial/Gen Z Leftists Are Emerging: Are Sociologists Ready for Them? Sociological Perspectives. Vol. 63. No. 3. P. 408-427. https://doi.org/ $10.1177 / 0731121420915868$. 
Miller J. D. (2011) Active, Balanced, and Happy: These Young Americans Are Not Bowling Alone. The Generation X Report. Vol. 1. No. 1. URL: https://Isay.org/GenX_Rept_Iss1. pdf (accessed: 22.08.2021).

Aanestad G. (1993) The Bust Generation: A Cohort Analysis: A Dissertation Submitted to the Graduate Division of the University of Hawaii in Partial Fulfillment of the Requirements for the Degree of Doctor of Philosophy in Political Sciences. URL: https:// scholarspace.manoa.hawaii.edu/handle/10125/10141 (accessed: 22.08.2021).

Rue P. (2018) Make Way, Millennials, Here Comes Gen Z. In: About Campus: Enriching the Student Learning Experience. Vol. 23. No. 3. P. 5-12. https://doi.org/10.1177/ 1086482218804251.

Schroth H. (2019) Are You Ready for Gen Z in the Workplace? California Management Review. Vol. 61. No. 3. P. 5-18. https://doi.org/10.1177/0008125619841006.

Strauss W., Howe N. (1991) Generations: The History of America's Future, 1584 to 2069. New York, NY: William Morrow \& Company.

Ueberwimmer M., Blyznyuk T. (2016) The Generation Theory: A Cross-Cultural Approach. Economics of Development. No. 2. P. 44-48. URL: http://www.ed.ksue.edu.ua/ER/ knt/eu162_78/e162ueb.pdf (accessed: 22.08.2021).

Yurchak A. (2006) Everything Was Forever, Until It Was No More: The Last Soviet Generation. Princeton, NJ: Princeton University Press. 